Published in final edited form as:

Ann Intern Med. 2012 January 3; 156(1_PART_1): 45-51. doi:

10.1059/0003-4819-156-1-201201030-00008.

\title{
Advanced Dementia: State of the Art and Priorities for the Next Decade
}

\author{
Susan L. Mitchell, MD, MPH, Betty S. Black, PhD, Mary Ersek, RN, PhD, Laura C. Hanson, \\ MD, MPH, Susan C. Miller, PhD, Greg A. Sachs, MD, Joan M. Teno, MD, MS, and R. Sean \\ Morrison, MD \\ Hebrew SeniorLife, Institute for Aging Research, Boston, Massachusetts; Johns Hopkins \\ University School of Medicine and Berman Institute of Bioethics, Baltimore, Maryland; School of \\ Nursing, University of Pennsylvania, Philadelphia, Pennsylvania; Center for Aging and Health, \\ University of North Carolina, Chapel Hill, North Carolina; Brown University Program in Public
}

\begin{abstract}
(C) 2012 American College of Physicians
Requests for Single Reprints: Susan L. Mitchell, MD, MPH, Hebrew SeniorLife, Institute for Aging Research, 1200 Centre Street, Boston, MA 02131.

Current Author Addresses: Dr. Mitchell: Hebrew SeniorLife, Institute for Aging Research, 1200 Centre Street, Boston, MA 02131. Dr. Black: Johns Hopkins University School of Medicine and Berman Institute of Bioethics, 1809 Ashland Avenue, Baltimore, MD 21205.

Dr. Ersek: School of Nursing, University of Pennsylvania, Room 329, Fagin Hall, 418 Curie Boulevard, Philadelphia, PA 19104-4217.

Dr. Hanson: Division of Geriatric Medicine and Center for Aging and Health, University of North Carolina, 5003 Old Clinic, CB 7550, Chapel Hill, NC 27599-7550.

Drs. Miller and Teno: Brown University Program in Public Health, Department of Health Services, Policy, and Practices, Alpert Medical School at Brown University, 121 South Main Street, Providence, RI 02912.

Dr. Sachs: Division of General Internal Medicine and Geriatrics, Indiana University School of Medicine and Indiana University for Aging Research, Regenstrief Institute, Inc., 1001 West 10th Street, OPW-M200, Indianapolis, IN 46202-2879.

Dr. Morrison: Department of Geriatrics, Box 1070, Mount Sinai School of Medicine, One Gustave L. Levy Place, New York, NY 10029.

The information presented in this article is based on Research in Advanced Dementia: State of the Science and Future Directions, a conference held in Boston on 20 June 2011. This conference was funded by the National Palliative Care Research Center. Participants included the authors of this report: a group of multidisciplinary senior investigators from across the United States who are focused on advanced dementia research. Each senior investigator was assigned to review, summarize, and present the existing literature on advanced dementia in a specific area (for example, cohort definitions, clinical course, outcomes, study design, health care utilization, strategies to improve care, and funding). Each presentation was followed by group discussion with the explicit purpose of reaching consensus about key findings that were well-established by the literature. After individual topic presentations, a broader group discussion was dedicated to reaching agreement about the remaining critical knowledge gaps and the overriding top research priorities for the field.

Potential Conflicts of Interest: Dr. Mitchell: Grant (money to institution): National Institutes of Health. Dr. Black: Employment: Johns Hopkins University; Grant (money to institution): National Institutes of Health, National Institute on Aging; Royalties: DEMeasure. Dr. Ersek: Grant (money to institution): National Institutes of Health; Support to travel to meetings for the study or other purposes: National Palliative Care Research Center. Grants/grants pending: New York Department of Health, National Institutes of Health. Dr. Miller: Support for travel to meetings for the study or other purposes: National Palliative Care Research Center; Support for travel to meetings for the study or other purposes (money to institution): National Palliative Care Research Center; Grants/grants pending: Alzheimer's Association; Grants/grants pending (money to institution): Alzheimer's Association. Dr. Sachs: Support for travel to meetings for the study or other purposes (money to institution): National Palliative Care Research Center; Consultancy: CVS Caremark; Grants/grants pending (money to institution): National Institutes of Health, Agency for Health-care Research and Quality, Alzheimer's Association, National Palliative Care Research Center, Retirement Research Foundation. Disclosures can also be viewed at www.acponline.org/authors/icmje/ConflictOfInterestForms.do?msNum=M11-2121.
\end{abstract}

Author Contributions: Conception and design: S.L. Mitchell, B.S. Black, L.C. Hanson, A. Sachs, R.S. Morrison.

Analysis and interpretation of the data: M. Ersek, S.C. Miller.

Drafting of the article: S.L. Mitchell, L.C. Hanson, A. Sachs, J.M. Teno, R.S. Morrison.

Critical revision of the article for important intellectual content: S.L. Mitchell, B.S. Black, M. Ersek, L.C. Hanson, S.C. Miller, A. Sachs, J.M. Teno, R.S. Morrison.

Final approval of the article: S.L. Mitchell, B.S. Black, M. Ersek, L.C. Hanson, S.C. Miller, A. Sachs, J.M. Teno, R.S. Morrison. Obtaining of funding: S.L. Mitchell.

Administrative, technical, or logistic support: S.L. Mitchell, R.S. Morrison.

Collection and assembly of data: S.L. Mitchell, M. Ersek, S.C. Miller. 
Health and Alpert Medical School at Brown University, Providence, Rhode Island; Indiana University School of Medicine and Indiana University for Aging Research, Regenstrief Institute, Indianapolis, Indiana; and Mount Sinai School of Medicine, New York, New York

\section{Abstract}

Dementia is a leading cause of death in the United States. This article outlines the current understanding of advanced dementia and identifies research priorities for the next decade. Research over the past 25 years has largely focused on describing the experience of patients with advanced dementia. This work has delineated abundant opportunities for improvement, including greater recognition of advanced dementia as a terminal illness, better treatment of distressing symptoms, increased access to hospice and palliative care services, and less use of costly and aggressive treatments that may be of limited clinical benefit. Addressing those opportunities must be the overarching objective for the field in the coming decade. Priority areas include designing and testing interventions that promote high-quality, goal-directed care; health policy research to identify strategies that incentivize cost-effective and evidence-based care; implementation studies of promising interventions and policies; and further development of disease-specific outcome measures. There is great need and opportunity to improve outcomes, contain expenditures, reduce disparities, and better coordinate care for the millions of persons in the United States who have advanced dementia.

More than 5 million Americans have Alzheimer disease, and this number is expected to reach 13 million by 2050 (1) (Figure 1). In 2009, Alzheimer disease was the sixth-leading cause of death in the United States, a ranking that has steadily risen during the past decade (2). Aggregate health care expenditures for dementia are projected to exceed $\$ 183$ billion in 2011 and reach $\$ 1.1$ trillion by 2050 (3). Expenditures are highest in late-stage disease, largely because of Medicaid spending for care at nursing homes (4), where approximately $70 \%$ of these patients die (5). Altogether, the societal burden of advanced dementia is substantial and increasing.

Advanced dementia has been relatively underrecognized as a terminal illness (6-8). Initiatives aimed at improving the experience of patients dying of this disease have lagged behind those of more commonly recognized life-threatening conditions, such as cancer. Advanced dementia emerged as a topic in the scientific literature approximately 25 years ago (9). Since then, research devoted to this field has increased (10). The objectives of this article are to outline our current understanding of advanced dementia and, with that foundation, identify the most pressing research priorities for the next decade.

\section{Current Understanding of Advanced Dementia}

\section{Clinical Course}

The last year of life in persons with advanced dementia differs from that of persons with other common causes of death, in that it is characterized by a prolonged trajectory of severe disability (11). The Global Deterioration Scale (12) is a validated and reliable instrument that describes the clinical progression of dementia (Table 1). The scale ranges from stages 1 to 7 , with higher scores indicating more severe dementia.

Stage 7 of the Global Deterioration Scale provides a useful description of the features of advanced dementia for clinical and research purposes: profound memory deficits (inability to recognize family members), speech limited to fewer than 5 words, total functional dependence, incontinence, and inability to ambulate. The CASCADE (Choices, Attitudes, and Strategies for Care of Advanced Dementia at the End-of-Life) study used this definition to describe the clinical course of 323 nursing home residents with advanced dementia (13). 
Over 18 months, $55 \%$ of the cohort died, $41 \%$ had pneumonia, $51 \%$ had a febrile episode, and $86 \%$ developed an eating problem. Other major acute illnesses (for example, hip fracture and myocardial infarction) were rare.

The CASCADE study thus confirmed that advanced dementia is characterized by a high mortality rate and the onset of infectious episodes and eating problems. Moreover, it demonstrated that most patients with advanced dementia die of this disease and its expected complications, not other acute illnesses.

\section{Prognosis}

Prognostication has important implications for clinical decision making and for accessing Medicare hospice benefits, which requires an estimated survival time of less than 6 months (13-15). The development of risk models for mortality that accurately estimate survival in advanced dementia has unfortunately proved elusive (16-21). In a prospective validation study (16), the 12-item Advanced Dementia Prognostic Tool predicted 6-month survival with only modest accuracy (area under the receiver-operating characteristic curve, 0.67); however, these findings were better than those of current Medicare hospice eligibility guidelines (area under the receiver-operating characteristic curve, 0.55) (16). The difficulty of estimating 6-month survival in advanced dementia suggests that access to palliative care for these patients should be guided not by their prognosis but rather by their preference to focus care on maximizing comfort and quality of life.

\section{Sources of Distress}

Patients with advanced dementia commonly experience distressing symptoms that are amenable to treatment $(6,13,22-29)$. In the CASCADE study, the proportion of nursing home residents with advanced dementia who experienced pain and dyspnea increased as death approached, in a pattern similar to that of patients with cancer who are dying (30). Assessing patients' symptom distress is difficult because of their loss of language skills, but advanced dementia-specific instruments have been developed that quantify symptoms on the basis of the observations of caregivers. Several measures have gained greater endorsement because of their favorable psychometric properties and increasing collective experience among investigators (31-34).

\section{Management of Common Complications}

Treatment decisions in advanced dementia should be guided by patients' care preferences as specified in advance directives or as perceived by their proxies. Goals of care must be used to guide initiation of new treatments, as well as the withdrawal of ongoing treatments. Most proxies state that comfort is the primary goal of care $(13,35)$, although patients with advanced dementia commonly receive treatments that are inconsistent with this goal (3643). Possible reasons underlying this disconnect include such factors as inadequate advance care planning $(40,43,44)$, the challenges of prognostication (16-21), providers giving misinformed and inconsistent counseling to proxies $(13,45)$, cultural influences $(43,46-48)$, limited access to high-quality palliative care that is tailored to the unique needs of patients with dementia $(7,39)$, and misaligned fiscal incentives in a fee-for-service health care system $(49,50)$.

Treatment choices regarding eating problems and infections are the most common decisions that proxies confront (51). A substantial body of research exists on managing feeding problems in advanced dementia $(41,44,52-60)$. This topic has served as the paradigm for approaching dementia as a terminal illness with respect to examination of outcomes, decision making, and health care utilization. 
Treatment options for feeding problems include continued assisted oral feeding (when possible) or tube feeding. In the United States, approximately one third of nursing home residents with advanced dementia who develop feeding problems are tube-fed (40).

However, observational studies have consistently failed to demonstrate any clinical benefits of this intervention in this population $(41,44,53)$. This evidence, together with an appreciation of eating problems as part of the natural history of advanced dementia, has led experts to advocate against the use of tube feeding in this condition $(53,55,61)$.

Decision making for infections involves whether to administer antimicrobials or to use supportive measures only. Antimicrobial use is extensive in advanced dementia (62-66) and increases as death approaches (66). Up to $40 \%$ of patients with advanced dementia receive antimicrobials in the last 2 weeks of life (66). The extent to which antimicrobials meaningfully extend life or improve comfort in these patients, for whom infections are often a terminal event, remains unclear $(38,65,67-69)$. Nursing home residents with advanced dementia are 3 times more likely than other residents to be colonized with antimicrobialresistant bacteria (70). Altogether, the widespread use of antimicrobials in advanced dementia raises concerns not only from the perspective of individual benefits and burdens near the end of life but also from a public health standpoint with respect to the emergence of antimicrobial-resistant bacteria.

\section{Health Care Utilization}

Approximately $16 \%$ of persons in the United States who die of dementia do so in hospitals (5). Nursing home residents with advanced dementia experience an average of 1.6 hospital transfers in the last 90 days of life (42), and residents living in regions with higher transfer rates experience worse end-of-life outcomes (43). Hospitalizations can be traumatic for these frail patients (37), as they receive care from unfamiliar providers and undergo uncomfortable tests and interventions $(36,38,42,42)$.

In the CASCADE study, hospitalizations accounted for 30\% of Medicare expenditures; care at skilled nursing facilities after hospitalization accounted for an additional 10\% (50). Research suggests that most conditions precipitating hospitalization in advanced dementia (for example, pneumonia) can be treated with the same efficacy in the community or nursing home setting $(64,65,71,72)$. For most patients for whom comfort is the priority $(13,35)$, hospitalization is seldom consistent with this goal, albeit with rare exceptions (for example, a hip fracture).

Hospice care is a beneficial $(26,73-75)$ yet under-utilized service in advanced dementia (7). Patients dying with dementia who received hospice care have better symptom management $(26,74)$, fewer terminal hospitalizations (76), and greater family satisfaction with care than those not receiving hospice care $(28,74)$. Trends indicate that hospice enrollment of patients with dementia is increasing; however, only $11 \%$ of hospice recipients in 2009 were reported to have a primary diagnosis of dementia, whereas $40 \%$ had cancer (77). Hospice professionals cite prognostication as the main hindrance to enrolling patients with dementia (78).

There are profound disparities in advanced dementia care. Nonwhite race is the most consistent risk factor associated with outcomes considered markers of poor-quality end-oflife care, including increased use of tube feeding (40), terminal hospitalizations (43), and lack of advance directives $(46,47)$. However, even after patient characteristics are controlled for, these outcomes vary dramatically across the United States in a strikingly consistent pattern, with a general propensity for worse quality of care in the southeast $(42,43,48,52$, $54,58,79)$. The reasons for these disparities remain unclear, but they underscore that care of advanced dementia care is driven by a complex interplay of individual preferences, cultural 
influences, regional market factors, facility characteristics, local practice patterns, and health care policies.

\section{Strategies to Improve Care}

Our understanding of successful strategies to improve care in advanced dementia is largely based on observational data. Modifiable factors most consistently shown to be associated with better palliative care outcomes for patients with advanced dementia in cohort studies include the presence of advance directives (for example, do-not-hospitalize orders) $(40,43-$ $45,50)$, better counseling of patients' health care proxies $(13,45)$, residence in a special care dementia unit $(45,51)$, use of hospice $(26,28,74,76,80)$, and the presence of nurse practitioners on-site in a nursing home $(40,47)$.

There are few randomized, controlled trials (RCTs) of interventions in advanced dementia, of which only 2 had adequate methodological rigor to warrant comment $(56,81)$. Both studies evaluated decision support tools. In one study, healthy elderly persons who were randomly assigned to watch a video showing a patient with advanced dementia were more likely to prefer comfort care (vs. life prolongation) than were persons who were randomly assigned to listen to a verbal description of advanced dementia (81). The second study was a cluster RCT in 24 nursing homes of a decision aid to help proxies of residents with advanced dementia make treatment decisions for feeding problems (56). Proxies in the intervention facilities (vs. the control facilities) had reduced decisional conflict, increased knowledge, and better communication with providers about feeding decisions.

\section{Research Priorities}

To date, research has largely focused on describing the experience of patients with advanced dementia and the care they receive. This work has delineated abundant opportunities for improvement. Addressing those opportunities must be the overarching objective for advanced dementia research in the coming decade. Table 2 shows the research priorities needed to achieve that objective, categorized by discipline; lists specific goals within each discipline; and provides examples of research initiatives for each goal.

Designing and testing interventions that promote high-quality, goal-directed care across health care settings will be a cornerstone for future research in advanced dementia. An example of such a study would be an RCT of an intervention to avoid unwanted hospitalizations of nursing home residents with advanced dementia whose goals of care are primarily comfort. Interventions that reduce disparities in the quality of care provided to patients with advanced dementia who are of various ethnic and racial backgrounds are also needed. Clinical trials in advanced dementia, while essential, will not be straightforward to conduct; interventions are often complex, settings are not well-suited to research (for example, nursing homes), and outcomes are challenging to define and measure. Nonetheless, the success of prior RCTs that faced similar challenges demonstrates that these hurdles can be overcome $(56,71,81,82)$.

Health policy research is essential to move advanced dementia care forward. A primary goal of this research should be to identify policies that incentivize cost-effective and evidencebased care without comprising the quality of palliative care provided to these vulnerable patients (49). Expanding access to the Medicare hospice benefit and broad-based palliative care programs is a key part of the equation. For example, prior work clearly shows that the 6-month hospice eligibility guidelines are problematic (16). Thus, research that explores novel approaches to enroll dementia patients into hospice is warranted. Comparative effectiveness research that evaluates different strategies to treat common complications (such as pneumonia) would also inform policy. 
The anticipated complexity of clinical interventions and policies to improve advanced dementia care necessitate the inclusion of implementation science as a key priority to ensure that they can be effectively translated into practice. The Patient Protection and Affordable Care Act presents a timely opportunity for demonstration projects that evaluate alternative financial structures to reduce unwarranted and unwanted hospitalizations for nursing home residents with advanced dementia, such as bundled payments or capitated programs, similar to the Program of All Inclusive Care for the Elderly (which integrates Medicare and Medicaid financing for frail elderly patients) (49).

Although progress has been made in outcomes measurement, many gaps remain. For example, there is no measure to quantify the stress that families of nursing home residents with advanced dementia experience. A disease-specific utility-based measure that takes into account health-related quality of life must be developed to conduct comparative and cost effectiveness research. Finally, greater delineation of meaningful effect sizes of existing measures is necessary to plan trials that will use these instruments as outcomes (31-34).

The research priorities set forth in this report align with those of the National Alzheimer's Project Act, which was signed into law in January 2011. This projects calls for the expansion and coordination of research and health services delivery across federal agencies for Alzheimer disease and related dementias in order to achieve 2 top priorities: improve the health outcomes of patients with dementia and reduce the financial burden of the disease at an individual and societal level. The act further prioritizes the need to reduce disparities and improve the coordination of dementia care, and it stresses the need for initiatives aimed at prevention and early detection of dementia. However, if the top priorities of the act are to be met, significant focus must be placed on the millions of persons in the United States in the advanced stage of the disease, for whom there is great need and opportunity to improve patient outcomes, contain health care expenditures, reduce disparities, and better coordinate care.

Accomplishing these priorities will depend on several factors, including research funding. To date, roughly $63 \%$ of advanced dementia research has been supported by grants from the National Institutes of Health. However, with the National Institutes of Health budget at unprecedented lows, greater support from other federal agencies and philanthropic sources will be critical. In addition, the number of senior researchers dedicated to this field is small. Ongoing work will require close collaboration and intellectual and financial investment into the training of young investigators. Dissemination of key research findings through the education of policy-makers, health care providers, and the public will be an essential step in translating this work into better advanced dementia care. Finally, the millions of Americans with dementia and their families are perhaps the most important stakeholders in this research. Ultimately, their advocacy and enfranchisement may play the greatest role in driving advanced dementia research forward through the next decade.

\section{Acknowledgments}

Grant Support: By the National Palliative Care Research Center and grants K24AG033640 (Dr. Mitchell) and K24AG022345 (Dr. Morrison) from the National Institute on Aging.

\section{References}

1. Hebert LE, Scherr PA, Bienias JL, Bennett DA, Evans DA. Alzheimer disease in the US population: prevalence estimates using the 2000 census. Arch Neurol. 2003; 60:1119-22. [PubMed: 12925369]

2. National Center for Health Statistics. [6 July 2011] National Vital Statistics Reports. 2011. Accessed at www.cdc.gov/nchs/data/nvsr/nvsr59/nvsr59_04.pdf 
3. Alzheimer's Association. [2 August 2011] Alzheimer's disease facts and figures. 2011. Accessed at www.alz.org/alzheimers_disease_facts_and_figures.asp

4. Zhu CW, Scarmeas N, Torgan R, Albert M, Brandt J, Blacker D, et al. Clinical features associated with costs in early AD: baseline data from the Predictors Study. Neurology. 2006; 66:1021-8. [PubMed: 16606913]

5. Mitchell SL, Teno JM, Miller SC, Mor V. A national study of the location of death for older persons with dementia. J Am Geriatr Soc. 2005; 53:299-305. [PubMed: 15673356]

6. Mitchell SL, Kiely DK, Hamel MB. Dying with advanced dementia in the nursing home. Arch Intern Med. 2004; 164:321-6. [PubMed: 14769629]

7. Sachs GA, Shega JW, Cox-Hayley D. Barriers to excellent end-of-life care for patients with dementia. J Gen Intern Med. 2004; 19:1057-63. [PubMed: 15482560]

8. Di Giulio P, Toscani F, Villani D, Brunelli C, Gentile S, Spadin P. Dying with advanced dementia in long-term care geriatric institutions: a retrospective study. J Palliat Med. 2008; 11:1023-8. [PubMed: 18788965]

9. Volicer L, Rheaume Y, Brown J, Fabiszewski K, Brady R. Hospice approach to the treatment of patients with advanced dementia of the Alzheimer type. JAMA. 1986; 256:2210-3. [PubMed: 3761520]

10. van der Steen JT. Dying with dementia: what we know after more than a decade of research. J Alzheimers Dis. 2010; 22:37-55. [PubMed: 20847433]

11. Gill TM, Gahbauer EA, Han L, Allore HG. Trajectories of disability in the last year of life. N Engl J Med. 2010; 362:1173-80. [PubMed: 20357280]

12. Reisberg B, Ferris SH, de Leon MJ, Crook T. The Global Deterioration Scale for assessment of primary degenerative dementia. Am J Psychiatry. 1982; 139:1136-9. [PubMed: 7114305]

13. Mitchell SL, Teno JM, Kiely DK, Shaffer ML, Jones RN, Prigerson HG, et al. The clinical course of advanced dementia. N Engl J Med. 2009; 361:1529-38. [PubMed: 19828530]

14. The National Hospice Organization. Medical guidelines for determining prognosis in selected noncancer diseases. Hosp J. 1996; 11:47-63. [PubMed: 8949013]

15. Weeks JC, Cook EF, O’Day SJ, Peterson LM, Wenger N, Reding D, et al. Relationship between cancer patients' predictions of prognosis and their treatment preferences. JAMA. 1998; 279:1709_ 14. [PubMed: 9624023]

16. Mitchell SL, Miller SC, Teno JM, Kiely DK, Davis RB, Shaffer ML. Prediction of 6-month survival of nursing home residents with advanced dementia using ADEPT vs hospice eligibility guidelines. JAMA. 2010; 304:1929-35. [PubMed: 21045099]

17. Mitchell SL, Kiely DK, Hamel MB, Park PS, Morris JN, Fries BE. Estimating prognosis for nursing home residents with advanced dementia. JAMA. 2004; 291:2734-40. [PubMed: 15187055]

18. Schonwetter RS, Han B, Small BJ, Martin B, Tope K, Haley WE. Predictors of six-month survival among patients with dementia: an evaluation of hospice Medicare guidelines. Am J Hosp Palliat Care. 2003; 20:105-13. [PubMed: 12693642]

19. Volicer BJ, Hurley A, Fabiszewski KJ, Montgomery P, Volicer L. Predicting short-term survival for patients with advanced Alzheimer's disease. J Am Geriatr Soc. 1993; 41:535-40. [PubMed: 8486888]

20. Marsh GW, Prochoda KP, Pritchett E, Vojir CP. Predicting hospice appropriateness for patients with dementia of the Alzheimer's type. Appl Nurs Res. 2000; 13:187-96. [PubMed: 11078784]

21. van der Steen JT, Mitchell SL, Frijters DH, Kruse RL, Ribbe MW. Prediction of 6-month mortality in nursing home residents with advanced dementia: validity of a risk score. J Am Med Dir Assoc. 2007; 8:464-8. [PubMed: 17845950]

22. McCarthy M, Addington-Hall J, Altmann D. The experience of dying with dementia: a retrospective study. Int J Geriatr Psychiatry. 1997; 12:404-9. [PubMed: 9152728]

23. Black BS, Finucane T, Baker A, Loreck D, Blass D, Fogarty L, et al. Health problems and correlates of pain in nursing home residents with advanced dementia. Alzheimer Dis Assoc Disord. 2006; 20:283-90. [PubMed: 17132974]

24. Aminoff BZ, Adunsky A. Dying dementia patients: too much suffering, too little palliation. Am J Hosp Palliat Care. 2005; 22:344-8. [PubMed: 16225356] 
25. Aminoff BZ, Adunsky A. Their last 6 months: suffering and survival of end-stage dementia patients. Age Ageing. 2006; 35:597-601. [PubMed: 16926196]

26. Miller SC, Mor V, Wu N, Gozalo P, Lapane K. Does receipt of hospice care in nursing homes improve the management of pain at the end of life? J Am Geriatr Soc. 2002; 50:507-15. [PubMed: 11943048]

27. Shega JW, Hougham GW, Stocking CB, Cox-Hayley D, Sachs GA. Pain in community-dwelling persons with dementia: frequency, intensity, and congruence between patient and caregiver report. J Pain Symptom Manage. 2004; 28:585-92. [PubMed: 15589083]

28. Shega JW, Hougham GW, Stocking CB, Cox-Hayley D, Sachs GA. Patients dying with dementia: experience at the end of life and impact of hospice care. J Pain Symptom Manage. 2008; 35:499507. [PubMed: 18261878]

29. Shega JW, Hougham GW, Stocking CB, Cox-Hayley D, Sachs GA. Management of noncancer pain in community-dwelling persons with dementia. J Am Geriatr Soc. 2006; 54:1892-7. [PubMed: 17198495]

30. McCarthy EP, Phillips RS, Zhong Z, Drews RE, Lynn J. Dying with cancer: patients' function, symptoms, and care preferences as death approaches. J Am Geriatr Soc. 2000; 48:S110-21. [PubMed: 10809464]

31. Volicer L, Hurley AC, Blasi ZV. Scales for evaluation of End-of-Life Care in Dementia. Alzheimer Dis Assoc Disord. 2001; 15:194-200. [PubMed: 11723370]

32. Volicer L, Hurley AC, Lathi DC, Kowall NW. Measurement of severity in advanced Alzheimer's disease. J Gerontol. 1994; 49:M223-6. [PubMed: 8056941]

33. Kiely DK, Volicer L, Teno J, Jones RN, Prigerson HG, Mitchell SL. The validity and reliability of scales for the evaluation of end-of-life care in advanced dementia. Alzheimer Dis Assoc Disord. 2006; 20:176-81. [PubMed: 16917188]

34. Warden V, Hurley AC, Volicer L. Development and psychometric evaluation of the Pain Assessment in Advanced Dementia (PAINAD) scale. J Am Med Dir Assoc. 2003; 4:9-15. [PubMed: 12807591]

35. Luchins DJ, Hanrahan P. What is appropriate health care for end-stage dementia? J Am Geriatr Soc. 1993; 41:25-30. [PubMed: 7678104]

36. Ahronheim JC, Morrison RS, Baskin SA, Morris J, Meier DE. Treatment of the dying in the acute care hospital. Advanced dementia and metastatic cancer. Arch Intern Med. 1996; 156:2094-100. [PubMed: 8862102]

37. Morrison RS, Ahronheim JC, Morrison GR, Darling E, Baskin SA, Morris J, et al. Pain and discomfort associated with common hospital procedures and experiences. J Pain Symptom Manage. 1998; 15:91-101. [PubMed: 9494307]

38. Morrison RS, Siu AL. Survival in end-stage dementia following acute illness. JAMA. 2000; 284:47-52. [PubMed: 10872012]

39. Mitchell SL, Morris JN, Park PS, Fries BE. Terminal care for persons with advanced dementia in the nursing home and home care settings. J Palliat Med. 2004; 7:808-16. [PubMed: 15684848]

40. Mitchell SL, Teno JM, Roy J, Kabumoto G, Mor V. Clinical and organizational factors associated with feeding tube use among nursing home residents with advanced cognitive impairment. JAMA. 2003; 290:73-80. [PubMed: 12837714]

41. Meier DE, Ahronheim JC, Morris J, Baskin-Lyons S, Morrison RS. High short-term mortality in hospitalized patients with advanced dementia: lack of benefit of tube feeding. Arch Intern Med. 2001; 161:594-9. [PubMed: 11252121]

42. Teno JM, Mitchell SL, Skinner J, Kuo S, Fisher E, Intrator O, et al. Churning: the association between health care transitions and feeding tube insertion for nursing home residents with advanced cognitive impairment. J Palliat Med. 2009; 12:359-62. [PubMed: 19327073]

43. Gozalo P, Teno JM, Mitchell SL, Skinner J, Bynum J, Tyler D, et al. End-of-life transitions among nursing home residents with cognitive issues. N Engl J Med. 2011; 365:1212-21. [PubMed: 21991894]

44. Mitchell SL, Kiely DK, Lipsitz LA. The risk factors and impact on survival of feeding tube placement in nursing home residents with severe cognitive impairment. Arch Intern Med. 1997; 157:327-32. [PubMed: 9040301] 
45. Engel SE, Kiely DK, Mitchell SL. Satisfaction with end-of-life care for nursing home residents with advanced dementia. J Am Geriatr Soc. 2006; 54:1567-72. [PubMed: 17038076]

46. Kiely DK, Mitchell SL, Marlow A, Murphy KM, Morris JN. Racial and state differences in the designation of advance directives in nursing home residents. J Am Geriatr Soc. 2001; 49:1346-52. [PubMed: 11890494]

47. Mitchell SL, Teno JM, Intrator O, Feng Z, Mor V. Decisions to forgo hospitalization in advanced dementia: a nationwide study. J Am Geriatr Soc. 2007; 55:432-8. [PubMed: 17341248]

48. Lopez RP, Amella EJ, Strumpf NE, Teno JM, Mitchell SL. The influence of nursing home culture on the use of feeding tubes. Arch Intern Med. 2010; 170:83-8. [PubMed: 20065203]

49. Ouslander JG, Berenson RA. Reducing unnecessary hospitalizations of nursing home residents. N Engl J Med. 2011; 365:1165-7. [PubMed: 21991889]

50. Goldfeld KS, Stevenson DG, Hamel MB, Mitchell SL. Medicare expenditures among nursing home residents with advanced dementia. Arch Intern Med. 2011; 171:824-30. [PubMed: 21220646]

51. Givens JL, Kiely DK, Carey K, Mitchell SL. Healthcare proxies of nursing home residents with advanced dementia: decisions they confront and their satisfaction with decision-making. J Am Geriatr Soc. 2009; 57:1149-55. [PubMed: 19486200]

52. Ahronheim JC, Mulvihill M, Sieger C, Park P, Fries BE. State practice variations in the use of tube feeding for nursing home residents with severe cognitive impairment. J Am Geriatr Soc. 2001; 49:148-52. [PubMed: 11207868]

53. Finucane TE, Christmas C, Travis K. Tube feeding in patients with advanced dementia: a review of the evidence. JAMA. 1999; 282:1365-70. [PubMed: 10527184]

54. Gessert CE, Mosier MC, Brown EF, Frey B. Tube feeding in nursing home residents with severe and irreversible cognitive impairment. J Am Geriatr Soc. 2000; 48:1593-600. [PubMed: 11129748]

55. Gillick MR. Rethinking the role of tube feeding in patients with advanced dementia. N Engl J Med. 2000; 342:206-10. [PubMed: 10639550]

56. Hanson LC, Carey TS, Caprio AJ, Lee TJ, Ersek M, Garrett J, et al. Improving decision making for feeding options in dementia care: a randomized trial. J Am Geriatr Soc. 2011; 59:2009-16. [PubMed: 22091750]

57. Monteleoni C, Clark E. Using rapid-cycle quality improvement methodology to reduce feeding tubes in patients with advanced dementia: before and after study. BMJ. 2004; 329:491-4. [PubMed: 15331474]

58. Teno JM, Mor V, DeSilva D, Kabumoto G, Roy J, Wetle T. Use of feeding tubes in nursing home residents with severe cognitive impairment [Letter]. JAMA. 2002; 287:3211-2. [PubMed: 12076216]

59. Teno JM, Mitchell SL, Kuo SK, Gozalo PL, Rhodes RL, Lima JC, et al. Decision-making and outcomes of feeding tube insertion: a five-state study. J Am Geriatr Soc. 2011; 59:881-6. [PubMed: 21539524]

60. Mitchell SL, Buchanan JL, Littlehale S, Hamel MB. Tube-feeding versus hand-feeding nursing home residents with advanced dementia: a cost comparison. J Am Med Dir Assoc. 2003; 4:27-33. [PubMed: 12807594]

61. Mitchell SL. A 93-year-old man with advanced dementia and eating problems. JAMA. 2007; 298:2527-36. [PubMed: 17986683]

62. Chen JH, Lamberg JL, Chen YC, Kiely DK, Page JH, Person CJ, et al. Occurrence and treatment of suspected pneumonia in long-term care residents dying with advanced dementia. J Am Geriatr Soc. 2006; 54:290-5. [PubMed: 16460381]

63. Mehr DR, van der Steen JT, Kruse RL, Ooms ME, Rantz M, Ribbe MW. Lower respiratory infections in nursing home residents with dementia: a tale of two countries. Gerontologist. 2003; 43(Spec No 2):85-93. [PubMed: 12711728]

64. van der Steen JT, Kruse RL, Ooms ME, Ribbe MW, van der Wal G, Heintz LL, et al. Treatment of nursing home residents with dementia and lower respiratory tract infection in the United States and The Netherlands: an ocean apart. J Am Geriatr Soc. 2004; 52:691-9. [PubMed: 15086647] 
65. Givens JL, Jones RN, Shaffer ML, Kiely DK, Mitchell SL. Survival and comfort after treatment of pneumonia in advanced dementia. Arch Intern Med. 2010; 170:1102-7. [PubMed: 20625013]

66. D’Agata E, Mitchell SL. Patterns of antimicrobial use among nursing home residents with advanced dementia. Arch Intern Med. 2008; 168:357-62. [PubMed: 18299489]

67. van der Steen JT, Ooms ME, Adèr HJ, Ribbe MW, van der Wal G. Withholding antibiotic treatment in pneumonia patients with dementia: a quantitative observational study. Arch Intern Med. 2002; 162:1753-60. [PubMed: 12153379]

68. Fabiszewski KJ, Volicer B, Volicer L. Effect of antibiotic treatment on outcome of fevers in institutionalized Alzheimer patients. JAMA. 1990; 263:3168-72. [PubMed: 1693407]

69. van der Steen JT, Mehr DR, Kruse RL, Sherman AK, Madsen RW, D'Agostino RB, et al. Predictors of mortality for lower respiratory infections in nursing home residents with dementia were validated transnationally. J Clin Epidemiol. 2006; 59:970-9. [PubMed: 16895821]

70. Pop-Vicas A, Mitchell SL, Kandel R, Schreiber R, D’Agata EM. Multidrug-resistant gramnegative bacteria in a long-term care facility: prevalence and risk factors. J Am Geriatr Soc. 2008; 56:1276-80. [PubMed: 18557965]

71. Loeb M, Carusone SC, Goeree R, Walter SD, Brazil K, Krueger P, et al. Effect of a clinical pathway to reduce hospitalizations in nursing home residents with pneumonia: a randomized controlled trial. JAMA. 2006; 295:2503-10. [PubMed: 16757722]

72. Fried TR, Gillick MR, Lipsitz LA. Whether to transfer? Factors associated with hospitalization and outcome of elderly long-term care patients with pneumonia. J Gen Intern Med. 1995; 10:246-50. [PubMed: 7616332]

73. Teno JM, Gozalo PL, Lee IC, Kuo S, Spence C, Connor SR, et al. Does hospice improve quality of care for persons dying from dementia? J Am Geriatr Soc. 2011; 59:1531-6. [PubMed: 21797834]

74. Kiely DK, Givens JL, Shaffer ML, Teno JM, Mitchell SL. Hospice use and outcomes in nursing home residents with advanced dementia. J Am Geriatr Soc. 2010; 58:2284-91. [PubMed: 21143437]

75. Miller SC, Intrator O, Gozalo P, Roy J, Barber J, Mor V. Government expenditures at the end of life for short- and long-stay nursing home residents: differences by hospice enrollment status. $\mathbf{J}$ Am Geriatr Soc. 2004; 52:1284-92. [PubMed: 15271115]

76. Miller SC, Gozalo P, Mor V. Hospice enrollment and hospitalization of dying nursing home patients. Am J Med. 2001; 111:38-44. [PubMed: 11448659]

77. National Hospice and Palliative Care Organization. [August 2 August 2011] Facts and Figures. 2010. Accessed at www.nhpco.org/i4a/pages/index.cfm?pageid=5994

78. Hanrahan P, Luchins DJ. Access to hospice programs in end-stage dementia: a national survey of hospice programs. J Am Geriatr Soc. 1995; 43:56-9. [PubMed: 7806741]

79. Mitchell SL, Kiely DK, Gillick MR. Nursing home characteristics associated with tube feeding in advanced cognitive impairment. J Am Geriatr Soc. 2003; 51:75-9. [PubMed: 12534849]

80. Teno JM, Clarridge BR, Casey V, Welch LC, Wetle T, Shield R, et al. Family perspectives on endof-life care at the last place of care. JAMA. 2004; 291:88-93. [PubMed: 14709580]

81. Volandes AE, Paasche-Orlow MK, Barry MJ, Gillick MR, Minaker KL, Chang Y, et al. Video decision support tool for advance care planning in dementia: randomised controlled trial. BMJ. 2009; 338:b2159. [PubMed: 19477893]

82. Loeb M, Brazil K, Lohfeld L, McGeer A, Simor A, Stevenson K, et al. Effect of a multifaceted intervention on number of antimicrobial prescriptions for suspected urinary tract infections in residents of nursing homes: cluster randomised controlled trial. BMJ. 2005; 331:669. [PubMed: $16150741]$ 


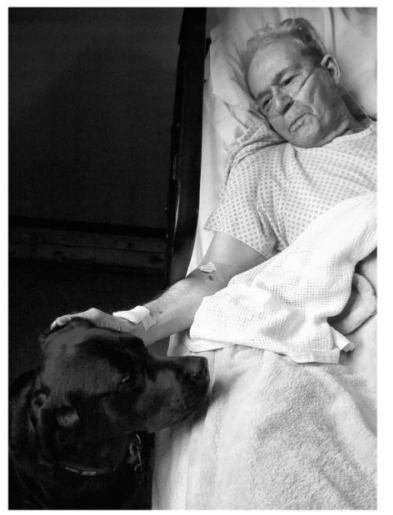

Figure .

A patient with dementia.

Published with permission of Lorraine O'Rourke. 
Table 1

\section{Stages of Dementia Described by the Global Deterioration Scale*}

\begin{tabular}{|c|c|}
\hline $\begin{array}{l}\text { Global } \\
\text { Deterioration } \\
\text { Scale Stage }\end{array}$ & General Features \\
\hline 1 & No subjective symptoms or clinical evidence of memory deficit. \\
\hline 2 & $\begin{array}{l}\text { Subjective symptoms of memory deficit, such as forgetting the location of familiar objects or previously well-known } \\
\text { names. }\end{array}$ \\
\hline 3 & $\begin{array}{l}\text { Early, clear-cut memory deficits, such as getting lost, poor work performance, problems with word or name finding, } \\
\text { misplacing objects of value, or poor retention of written material. }\end{array}$ \\
\hline 4 & $\begin{array}{l}\text { Clear-cut memory deficits, such as poor knowledge of current events, difficulty remembering details of personal history, } \\
\text { impaired concentration doing serial subtractions, and inability to handle finances or travel to new places. Frequently, } \\
\text { there is no deficit in orientation to time and place, recognition of familiar faces, or travel to familiar locations. }\end{array}$ \\
\hline 5 & $\begin{array}{l}\text { Can no longer function without some assistance. Unable to recall major aspects of current life (e.g., address, telephone } \\
\text { number, names of family members). May need assistance dressing, but still independent in eating and toileting. }\end{array}$ \\
\hline 6 & $\begin{array}{l}\text { Occasionally forgets name of primary caregiver (e.g., spouse). Largely unaware of recent personal events. Substantial } \\
\text { assistance required with activities of daily living and travel to familiar locations. Often unaware of surroundings (e.g., } \\
\text { year or season). Can still recall his or her own name and distinguish a familiar face. }\end{array}$ \\
\hline 7 & $\begin{array}{l}\text { Unable to recognize familiar faces, verbal abilities limited to }<5 \text { words, incontinent of urine and stool, total functional } \\
\text { dependence, and unable to walk. }\end{array}$ \\
\hline
\end{tabular}


Table 2

Priorities for Advanced Dementia Research Over the Next Decade

\begin{tabular}{|c|c|c|}
\hline Discipline & Broad Research Objectives & Specific Examples \\
\hline Intervention & $\begin{array}{l}\text { Design and conduct RCTs of interventions to } \\
\text { promote high-quality, goal-directed care across } \\
\text { health care settings } \\
\text { Design and conduct RCTs of interventions to } \\
\text { reduce disparities in end-of-life care }\end{array}$ & $\begin{array}{l}\text { RCT of an intervention to reduce hospital transfers for nursing } \\
\text { home residents with advanced dementia whose goal of care is } \\
\text { comfort } \\
\text { RCT of a clinical pathway to reduce feeding tube insertions in } \\
\text { hospitalized patients with advanced dementia } \\
\text { RCT of culturally sensitive video decision aids that use visual } \\
\text { images (vs. verbal explanations) to illustrate treatment options }\end{array}$ \\
\hline Health policy/services & $\begin{array}{l}\text { Identify policies that incentivize high-quality, cost- } \\
\text { effective end-of-life care } \\
\text { Test strategies to increase access to hospice care } \\
\text { and palliative care programs } \\
\text { Conduct comparative effectiveness research of } \\
\text { treatment strategies }\end{array}$ & $\begin{array}{l}\text { Develop and evaluate nursing home quality indicators for end- } \\
\text { of-life care } \\
\text { Examine effect of introducing payment for hospice during } \\
\text { receipt of skilled nursing facility care } \\
\text { Determine the incremental cost-effectiveness ratio of not } \\
\text { hospitalizing nursing home residents with advanced dementia } \\
\text { for suspected pneumonia (e.g., incremental changes in quality- } \\
\text { adjusted outcomes relative to costs) }\end{array}$ \\
\hline Implementation & $\begin{array}{l}\text { Conduct projects to implement proven interventions } \\
\text { and policies }\end{array}$ & $\begin{array}{l}\text { Demonstration project of evidence-based advanced dementia } \\
\text { care intervention into nursing home practice }\end{array}$ \\
\hline Measurement & $\begin{array}{l}\text { Develop new advanced dementia-specific } \\
\text { instruments for outcomes currently lacking valid } \\
\text { measures } \\
\text { Better establish psychometric properties of existing } \\
\text { instruments }\end{array}$ & $\begin{array}{l}\text { Measure of stress among family members of nursing home } \\
\text { residents with advanced dementia } \\
\text { Develop utility-based measures of health-related quality of life } \\
\text { in order to conduct comparative effective research } \\
\text { Determine minimally clinically important difference for } \\
\text { Symptom Management at the End-of-Life in Dementia Scale } \\
\text { (30) }\end{array}$ \\
\hline
\end{tabular}

$\mathrm{RCT}=$ randomized, controlled trial. 